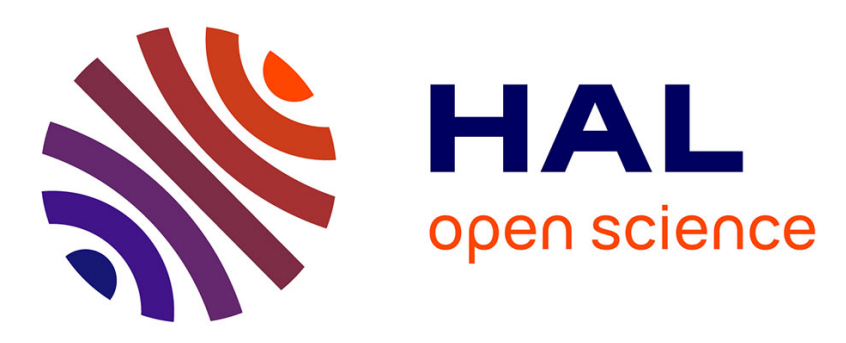

\title{
An innovative approach for on-demand hydrogen generation, application to the preparation of kraft black liquor foams
}

Vincent Lê, Marie-Anne Dourges, Jean-Louis Bobet, Hervé Deleuze

\section{- To cite this version:}

Vincent Lê, Marie-Anne Dourges, Jean-Louis Bobet, Hervé Deleuze. An innovative approach for ondemand hydrogen generation, application to the preparation of kraft black liquor foams. New Journal of Chemistry, 2020, 44 (40), pp.17518-17522. 10.1039/D0NJ03310C . hal-03008073

\section{HAL Id: hal-03008073 https://hal.science/hal-03008073}

Submitted on 16 Nov 2020

HAL is a multi-disciplinary open access archive for the deposit and dissemination of scientific research documents, whether they are published or not. The documents may come from teaching and research institutions in France or abroad, or from public or private research centers.
L'archive ouverte pluridisciplinaire HAL, est destinée au dépôt et à la diffusion de documents scientifiques de niveau recherche, publiés ou non, émanant des établissements d'enseignement et de recherche français ou étrangers, des laboratoires publics ou privés. 


\title{
An Innovative approach for on-demand hydrogen generation, application to the preparation of kraft black liquor foams
}

\author{
Vincent Lê $\hat{e}^{1,2}$, Marie-Anne Dourges ${ }^{1}$, Jean-Louis Bobet ${ }^{2} *$ Hervé Deleuze $^{1 *}$ \\ ${ }^{1}$ University of Bordeaux, Institut des Sciences Moléculaires (ISM), UMR-CNRS 5255, 351 Cours \\ de la Libération, F-33405 Talence, France. \\ ${ }^{2}$ ICMCB-CNRS- Université de Bordeaux, 87 Avenue du Dr Schweitzer,F-33600 Pessac, France.
} *Corresponding authors: Hervé Deleuze: herve.deleuze@u-bordeaux.fr, jean-
louis.bobet@icmcb.cnrs.fr

\begin{abstract}
A safe, cheap and straightforward on-demand hydrogen generation method has been developed using a polymethylhydrosiloxane (PMHS) emulsion as hydride donor in highly alkaline solution without the need of any other harmful catalyst. This system was used as chemical blowing agent for the preparation of kraft black liquor foams.
\end{abstract}

\section{Introduction}

On-demand hydrogen generation is desired for fuel cells, energy storage, and clean energy applications. ${ }^{1}$ Numerous research are conducted worldwide on clean, portable, cheap and reusable processes for hydrogen production. Five main way to produce clean hydrogen can be identified : electrochemical, photochemical, biochemical, thermochemical and radiochemical methods. ${ }^{2,3,4}$. The hydrolysis catalysed with magnesium appears as a promising route as magnesium waste parts can be used and also because the by-product (i.e. $\mathrm{Mg}(\mathrm{OH})_{2}$ ) is not hazardous. ${ }^{5}$

Among the numerous different systems proposed, the use of polymethylhydrosiloxane (PMHS) as hydrogen atom donor was scarcely mentioned. ${ }^{6}$ PHMS, a by-product of the silicone industry, is an inexpensive, easy-to-handle and environmentally friendly agent. PMHS can be stored for long periods without loss of activity. In aqueous alkaline solution, its hydrolysis is generally considered as very slow ${ }^{7}$ and has to be catalyzed by species such as amines, ${ }^{6}$ or hexamethylphosphoramide (HMPA). ${ }^{8}$

In that later case, hydrogen is released quickly and quantitatively at room temperature, leaving harmless silicate derivatives. However, the use of the highly toxic HMPA remains a problem even if its grafting onto polystyrene beads has been proposed. ${ }^{8}$ 
Kraft pulping is the most widely used process in the industrial production of cellulosic chemical pulp from wood. During the kraft process, lignin is degraded and dissolved almost completely, and thus separated from the insoluble cellulosic pulp. The resulting aqueous solution containing the inorganic and organic by-products of the process is called black liquor. ${ }^{9}$ Its chemical composition depends on the type of raw material processed, i.e. softwoods (such as pine), hardwoods (e.g. eucalyptus) or fibrous plants (like bamboo), as well as on the operational conditions of the pulping stage. ${ }^{10}$ However, in any case, black liquor can be considered as a complex, strongly alkaline aqueous solution, containing organic biomass materials (lignin, non-cellulosic polysaccharides called hemicelluloses and resinous compounds of low molar mass) and inorganic compounds (mainly soluble ion salts). ${ }^{11}$ In chemical pulp mills, about half of the original raw wood material is dissolved in black liquor. In modern pulp mills, the organic content of that liquor is used as lowgrade fuel and the inorganic chemicals recovered. Recently, several more attractive uses of industrial lignin contained in black liquor have been reported for the preparation of high addedvalue chemicals after their extraction and separation. ${ }^{12}$ However, the separation and purification processes needed to obtain these starting materials are time and energy consuming and may preclude their full uses. ${ }^{13}$

The demand for lightweight biobased materials has been on the rise in many industries, particularly the automotive, aerospace, construction, and packaging industries. Thus far, polymeric foams have met and will continue to meet these material demands, as their structure can be carefully tailored to the specific end application.

In this context, the conversion of raw black liquor into foams have been proposed using the emulsion-templating technique. ${ }^{14,15,16,17,18}$ The frothing approach has also being investigated. ${ }^{19}$ However, the most common way to prepare polymers foams such as polyurethane or epoxy foams remains the use of physical and chemical blowing agents. This approach has not yet being reported in the case of kraft black liquor.

Chemical blowing agents (CBA) produce gas by a chemical reaction. The reaction may be a thermal decomposition or a reaction between two components. It should occur over a well-defined temperature and time range. The most common CBA such as azodicarbonamide or sodium bicarbonate decomposes at rather high temperature $150-200^{\circ} \mathrm{C} .{ }^{20}$ and therefore appears difficult to apply for black liquor alkaline solution foaming.

The aim of this study is twofold: i) to demonstrate that the PMHS could permit, without the addition of any harmful catalyst, the production of dihydrogen with a suitable yield and possibly a good kinetics ; ii) to prepare black liquor-based solid macroporous foams using PHMS as a safe, simple and efficient chemical blowing agent.

The mechanism of the hydrogen production with PMHS in alkaline media can be written as 
follow :

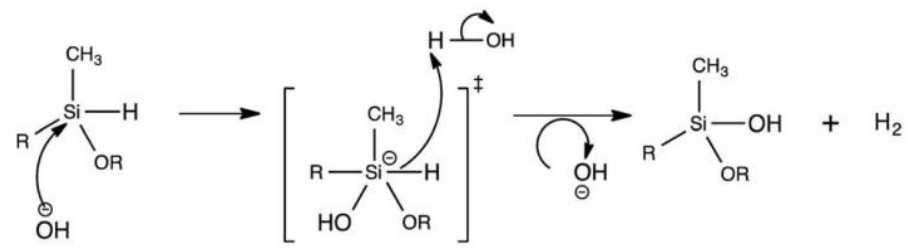

reaction (1)

This mechanism is based on the recovery of one atom of hydrogen from the PMHS and another one from the water molecule. The main issue with this reaction is the kinetic. It has been demonstrated that it was necessary to add a catalyst. ${ }^{4,5}$

Our goal was to remove this catalyst (because it can be expensive and hazardous). We present here the development of an improved method allowing this abstraction. This new safe and efficient way of hydrogen generation was then tested as blowing agent for black-liquor based solid foams.

\section{Experimental}

\section{Materials}

Crude kraft black liquor (BL) with 60 wt.\% solute, including lignin and hemicellulose as the organic components and sodium, potassium salts as inorganic components, was kindly supplied by a paper mill (Smurfit Kappa Cellulose du Pin Kraft paper mill, Facture, France). Its physicochemical properties have already being published. ${ }^{21}$ Dimethylsiloxane-60\% graft-propylene oxide $40 \%$ (surfactant A) and dimethylsiloxane-45\% graft-propylene oxide - 55\% block copolymers (surfactant B) were purchased from FluoroChem (France). Sodium trimetaphosphate (STMP) and polymethylhydrosiloxane (PMHS) were purchased from Sigma-Aldrich (France). All the chemicals were used as received.

\section{Hydrogen generation kinetic experiments}

For each experiments, PMHS (0.11g) and surfactant A or B (0.06 g), were thoroughly mixed on a $\mathrm{KOH}$ solution $(10 \mathrm{~mL})$ with concentrations ranging from 5 to $40 \mathrm{wt} \%$. The surfactants used were dimethylsiloxane-graft-propylene oxide with different dimethylsiloxane/propylene oxide ratio : 60/40 for surfactant A and 45/55 for surfactant B. The two different surfactants were chosen in order to vary the ratio between the hydrophobic (dimethylsiloxane) and hydrophilic (propylene oxide) phases. With such reaction condition, the theoretical amount of $\mathrm{H}_{2}$ produced is about $41 \mathrm{ml}$. The hydrolysis reaction was carried out at controlled temperature from room temperature to $80^{\circ} \mathrm{C}$. The 
experimental setup is detailed in reference. ${ }^{22}$ Hydrogen production is presented both as gas volume generation (in $\mathrm{mL}$ ) and as the conversion yield (\%). This latest is defined as the volume of produced hydrogen over the theoretical volume (when all the hydrogen from PMHS and $\mathrm{KOH}$ is completely consumed).

\section{Production of black liquor foams}

PMHS-in-water emulsions were prepared by dispersing PMHS $(0.2 \mathrm{~g})$ on a water solution (4 ml) containing surfactant B (0.15 g) using an Ultra Turrax disperser at different speeds for $5 \mathrm{~min}$. The PMHS-in-water emulsion was then rapidly added to $30 \mathrm{~g}$ of $60 \mathrm{wt} . \%$ solute black liquor solution in a glass tube $(\varnothing=40 \mathrm{~mm})$ and the mixture briefly and gently stirred with a spatula. In some formulations STMP (2g) was also added as crosslinking agent. A smooth and regular foaming is quickly observed. After stopping the foaming, the sample is allowed to cure at room temperature for 24 hours, demoulded, exhaustively washed with boiling water, then dried at $80^{\circ} \mathrm{C}$ until constant weight without any shrinkage.

\section{Instrumentation}

The apparent (bulk) density, the porosity $\mathrm{P}$ and the median pore size of each sample were determined by mercury intrusion porosimetry in a Micromeritics Autopore IV 9500 porosimeter (Micromeritics Corp., Norcross, GA, USA), with the following parameters: contact angle $=130$, mercury surface tension $=485 \mathrm{mN} . \mathrm{m}^{-1}$, maximum intrusion pressure $=124 . \mathrm{MPa}$.

The skeletal density $\rho_{\mathrm{s}}$ of the materials was determined using a Micromeritics Accupyc 1330 helium pycnometer (Micromeritics Corp., Norcross, GA, USA).

The specific surface area was determined by nitrogen sorption measurements with a Micromeritics ASAP 2010 analyzer (Micromeritics Corp., Norcross, GA, USA). The collected data were subjected to the Brunauer, Emmett and Teller (BET) treatment. ${ }^{23}$

The morphology of the monoliths was observed by scanning electron microscopy (SEM) in a Hitachi TM-1000 microscope. Photographs were taken at several magnifications between $\times 250$ and $\times 1000$. Pieces of foam (section of about $0.5 \mathrm{~cm}^{2}$ ) cut from the corresponding monoliths were mounted on a carbon tab which ensured a good conductivity. A thin layer of gold-palladium was sputtered on the samples fragment prior to analysis.

\section{Results and discussion}

Hydrogen generation with PMHS 
As shown in figure 1, hydrogen production in alkaline solution with PMHS alone is rather limited with a maximum yield of about $45 \%$ (i.e. about $18 \mathrm{ml}$ for $0.11 \mathrm{~g}$ of silane) (black line). The positive effect of the addition of a surfactant on the hydrogen generation yield is evidenced on figure 1 . Surfactant A allows to reach $75 \%$ yield in 10 min (red line) whereas a $90 \%$ yield is obtained in 20 min with surfactant B (blue line). The kinetic is also improved significantly with both surfactants, 25 and $27 \mathrm{ml}$ of $\mathrm{H}_{2}$ (i.e. 227 and $245 \mathrm{ml.g}^{-1}$ ) being produced respectively after $5 \mathrm{~min}$. Increasing the amount of hydrophilic phase in the surfactant (i.e. changing from surfactant A to surfactant B) allows a more stable emulsion and then an increase of the $\mathrm{H}_{2}$ production.

By these experiments, we have demonstrated that the use of a PMHS-in-water emulsion allows to have some $\mathrm{H}_{2}$ production without any catalyst.

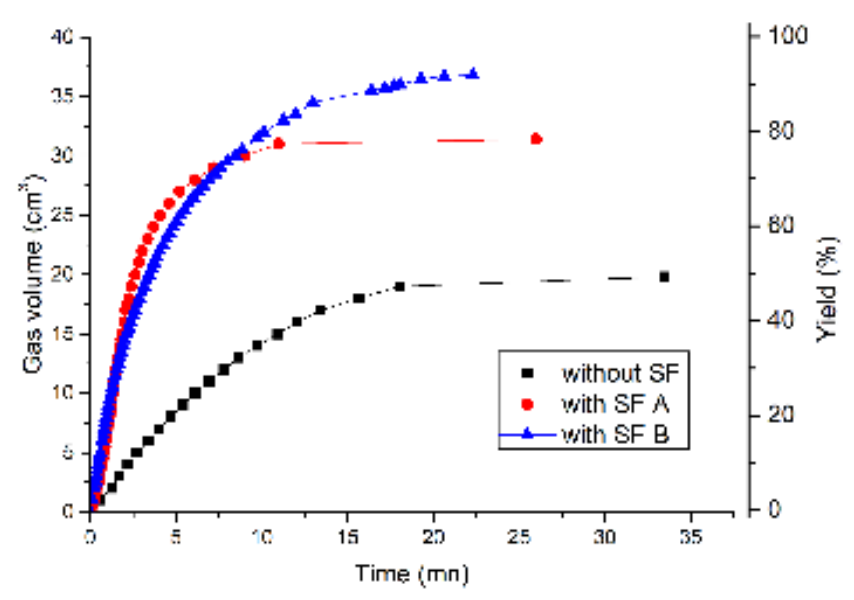

Figure 1 : Impact of the utilisation of a PMHS-in-water emulsion on hydrogen generation on an alkaline media.

\section{Effect of $\mathrm{KOH}$ solution concentration :}

An alkaline media, and more particularly the presence of hydroxyl ions, is essential in the $\mathrm{H}_{2}$ generation process. Therefore, it is important to get more information about the influence of their concentration in the reaction medium. The concentration range studied here was from $5 \mathrm{wt} \%$ up to 40wt.\%. As presented in figure 2, when the $\mathrm{KOH}$ concentration is low (i.e. $5 \mathrm{wt} . \%$ ) the production of hydrogen is almost nil (red line). Increasing the $\mathrm{KOH}$ concentration up to $30 \mathrm{wt} \%$ leads to a regular increase of both the kinetic and the yield of $\mathrm{H}_{2}$ production (reaching almost $90 \%$ in 20 minutes). However, a further increase in concentration up to $40 \mathrm{wt} \%$ lowered the yield to about $60 \%$. It is worth pointing out that increasing the $\mathrm{KOH}$ concentration up to 50 or $60 \mathrm{wt}$. $\%$ leads to an almost constant yield (not presented). 


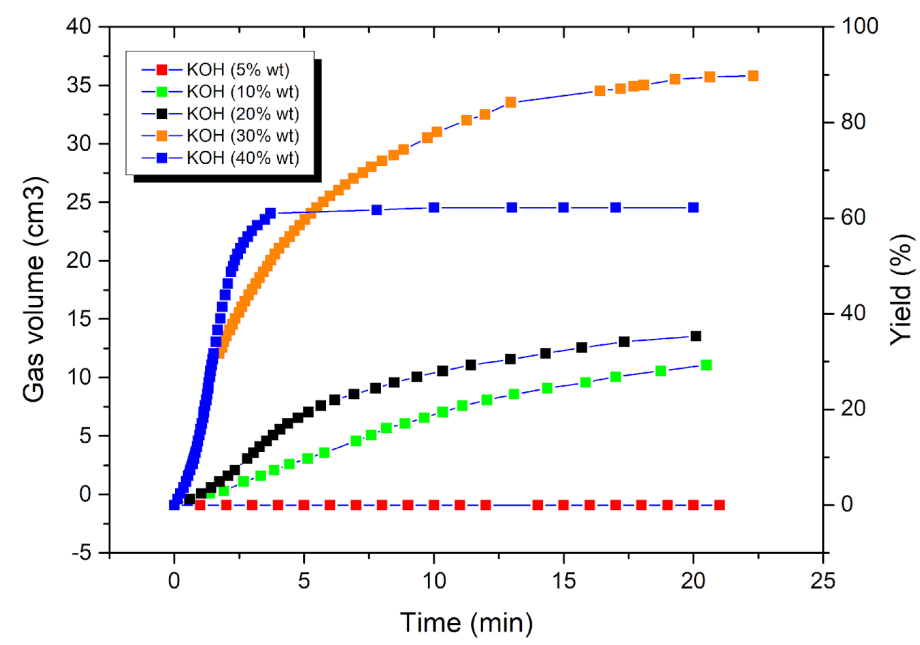

Figure 2 : Impact of the concentration of potassium hydroxide on hydrogen production rate and yield

It is possible to propose a tentative reaction mechanism for the production of hydrogen (figure 3):

1 - Formation of PMHS-in-water micelles droplets,

2 - Interfacial contact between an $\mathrm{OH}^{-}$ion and PMHS,

3 - Alkaline catalysed hydrolysis of PMHS (reaction 1) takes place and a molecule of $\mathrm{H}_{2}$ is produced on the droplet interface,

4 - Hydrogen bubble grows on the interface,

5 - A bubble of dihydrogen is generated and goes up to the surface of the solution.
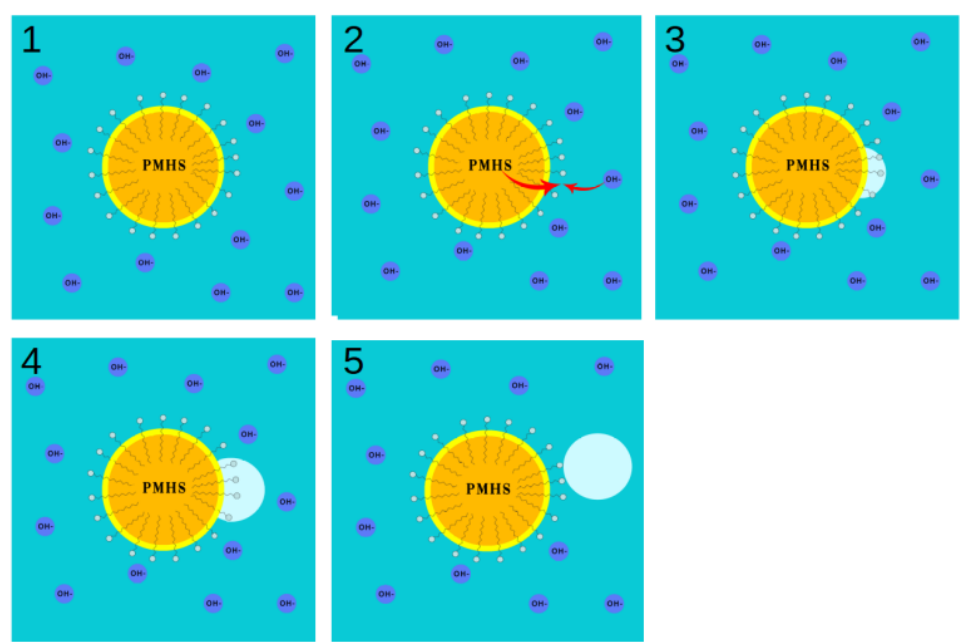

Figure 3 : Mechanism of hydrogen production using PHMS-in-water emulsion on potassium hydroxide solution.

\section{Effect of the temperature}


The effect of temperature on the yield and reaction rate has been studied. The reaction was performed at various temperature ranging from 30 to $70^{\circ} \mathrm{C}$. The results are presented on figure 4 . As expected, the temperature increase induces an increase of the reaction rate.

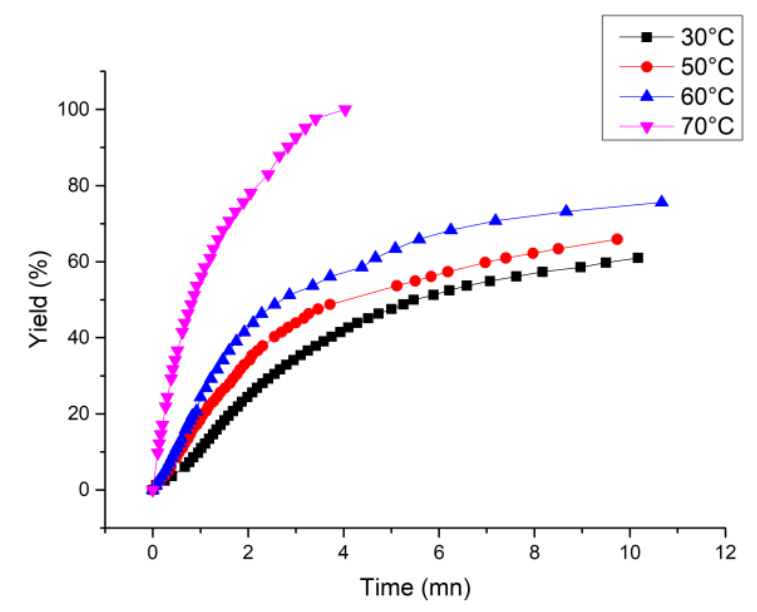

Figure 4 : Evolution of yield of hydrogen production with temperature.

From data reported on figure 4 , it is possible to determine the initial reaction rate : $91.10^{-3}, 122.10^{-}$ ${ }^{3}, 155.10^{-3}$ and $262.10^{-3} \mathrm{ml} \cdot \mathrm{s}^{-1}$ at $30,50,60$ and $70^{\circ} \mathrm{C}$ respectively. From these values, it was possible to estimate the activation energy of the reaction. Such result can be compared with the activation energy of other method to produce hydrogen on-demand reported on the literature (Table 1).

Table 1 : Comparison of activation energy of different methods to produce hydrogen on-demand.

\begin{tabular}{|c|c|c|}
\hline Hydride donor & $\begin{array}{c}\text { Activation energy } \\
\left(\mathrm{kJ} \cdot \mathrm{mol}^{-1}\right)\end{array}$ & references \\
\hline PHMS & 26.30 & This work \\
\hline $\mathrm{Mg}-\mathrm{Ni}-\mathrm{C}$ & 14.34 & 24 \\
\hline $\mathrm{Mg}-\mathrm{Nb}_{2} \mathrm{O}_{5}$ & 31.50 & 25 \\
\hline $\mathrm{Mg}-\mathrm{MoS}_{2}$ & 12.90 & 26 \\
\hline $\mathrm{Mg}-\mathrm{Mg}_{2} \mathrm{Cu}$ & 36.91 & 27 \\
\hline $\mathrm{Mg}-2.7 \mathrm{Ni}-1 \mathrm{Sn}$ & 43.13 & \\
\hline
\end{tabular}

As can be seen from the results reported on Table 1, our method appears fully competitive in term of activation energy. The hydrogen production is almost $90 \%$ of the theoretical hydrogen generation yield in $20 \mathrm{~min}$.

Hydrogen generation using PMHS-in-water emulsion appears to be an attractive approach. Therefore, we decided to apply this straightforward system to the foaming of black liquor solutions. 
An aliquot of pre-formed PMHS-in-water emulsion was rapidly mixed with the highly viscous strongly alkaline black liquor solution initiating its foaming through hydrogen bubbles generation. Sodium trimetaphosphate (STMP) was used as crosslinking agent in some formulations ${ }^{28}$ in order to investigate its influence on the foaming process. The influence of the stirring rate during the PMHSin-water preparation was also considered. Details of these formulations are reported on Table 2.

Table 2. Formulation of black liquor foams

\begin{tabular}{ccc}
\hline Sample & $\begin{array}{c}\text { Crosslinking } \\
\text { agent amount }(\mathrm{g})\end{array}$ & $\begin{array}{c}\text { Emulsion } \\
\text { stirring speed } \\
(\mathrm{rpm})\end{array}$ \\
\hline CBL-1 & 2 & 5000 \\
CBL-2 & 2 & 10000 \\
CBL-3 & 2 & 15000 \\
CBL-4 & 2 & 20000 \\
CBL-5 & 0 & 5000 \\
CBL-6 & 0 & 10000 \\
CBL-7 & 0 & 15000 \\
CBL-8 & 0 & 20000
\end{tabular}

From the visual observation of the height of foaming on the glass tube, the volume of hydrogen generated can be estimated to about $200 \mathrm{ml} \cdot \mathrm{g}^{-1}$. This value is in accordance with the $\mathrm{H}_{2}$ yields obtained in concentrated $\mathrm{KOH}$. The porous morphology of the foams were analysed and the results are reported in Table 3. Representative aspects of the foams are shown on Figures 5 and 6.

Figure 5 : Visual aspect of representative black liquor foams

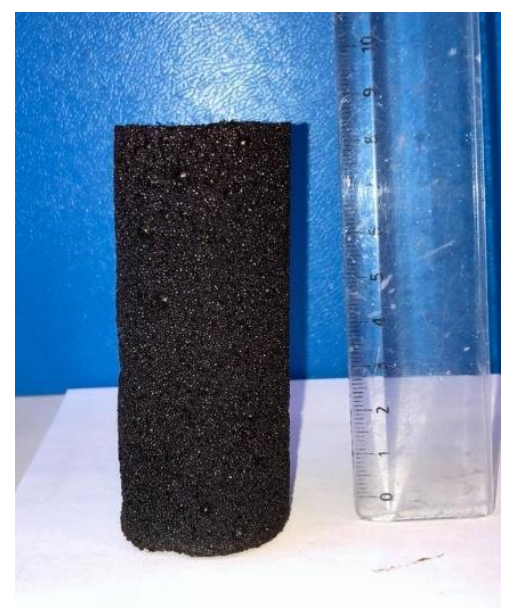




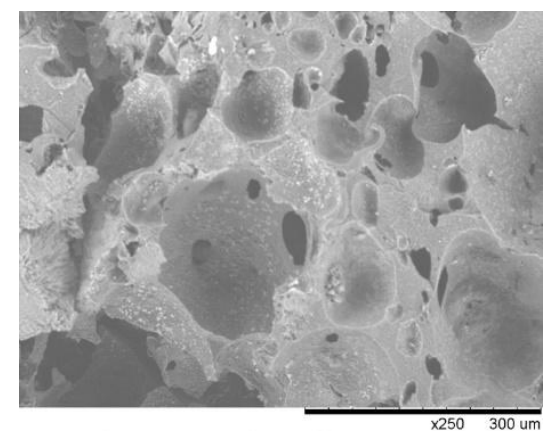

Figure 6 : SEM microphotography of a representative black liquor foam

Table 3. Morphology of black liquor foams.

\begin{tabular}{|c|c|c|c|c|c|c|}
\hline Sample & $\begin{array}{c}\text { Total } \\
\text { Intrusion } \\
\text { volume }^{\mathrm{a}} \\
\left(\mathrm{ml.g}^{-1}\right)\end{array}$ & $\begin{array}{l}\text { Median pore } \\
\text { diameter }^{\mathrm{a}} \\
(\mu \mathrm{m})\end{array}$ & $\begin{array}{c}\text { Bulk density }^{\text {a }} \\
\quad\left(\mathrm{mlL}^{\left.-g^{-1}\right)}\right.\end{array}$ & $\begin{array}{c}\text { Apparent } \\
\text { density }^{b} \\
\left(\mathrm{ml}^{-1} \mathrm{~g}^{-1}\right)\end{array}$ & $\begin{array}{c}\text { Porosity } \\
(\%)\end{array}$ & $\begin{array}{c}\text { BET Specific } \\
\operatorname{area}^{c} \\
\left(\mathbf{m}^{2} \cdot \mathrm{g}^{-1}\right)\end{array}$ \\
\hline CBL-1 & $1.26 \pm 0.03$ & $189 \pm 4$ & $0.53 \pm 0.05$ & $1.61 \pm 0.05$ & $67 \pm 3$ & $3.0 \pm 0.1$ \\
\hline CBL-2 & $1.27 \pm 0.03$ & $110 \pm 3$ & $0.56 \pm 0.023$ & $1.91 \pm 0.06$ & $71 \pm 4$ & $2.5 \pm 0.3$ \\
\hline CBL-3 & $1.43 \pm 0.03$ & $109 \pm 3$ & $0.50 \pm 0.05$ & $1.81 \pm 0.06$ & $72 \pm 3$ & $2.0 \pm 0.1$ \\
\hline CBL-4 & $1.80 \pm 0.05$ & $76 \pm 3$ & $0.42 \pm 0.04$ & $1.74 \pm 0.05$ & $76 \pm 3$ & $3.9 \pm 0.1$ \\
\hline CBL-5 & $0.55 \pm 0.03$ & $69 \pm 2$ & $0.91 \pm 0.023$ & $1.84 \pm 0.06$ & $50 \pm 4$ & $2.6 \pm 0.3$ \\
\hline CBL-6 & $0.82 \pm 0.02$ & $47 \pm 2$ & $0.73 \pm 0.03$ & $1.77 \pm 0.03$ & $59 \pm 2$ & $2.1 \pm 0.2$ \\
\hline CBL-7 & $0.89 \pm 0.03$ & $38 \pm 3$ & $0.70 \pm 0.023$ & $1.87 \pm 0.06$ & $62 \pm 4$ & $4.0 \pm 0.3$ \\
\hline CBL-8 & $1.07 \pm 0.02$ & $28 \pm 2$ & $0.63 \pm 0.05$ & $1.90 \pm 0.06$ & $67 \pm 3$ & $1.6 \pm 0.1$ \\
\hline
\end{tabular}

${ }^{a}$ determined by $\mathrm{Hg}$ porosimetry, ${ }^{\mathrm{b}}$ determined by He pycnometry, ${ }^{\mathrm{c}}$ determined by $\mathrm{N}_{2}$ adsorption.

From the results reported in Table 3, it can be seen that the use of a crosslinking agent on the formulation allows obtaining more porous foams probably by increasing the foam stability at the end of the blowing process (CBL 1-4 vs CBL 5-8). An increase of the stirring speed during the preparation of the PMHS emulsion allows to reduce the foam pore diameter. This effect may be attributed to a higher dispersion of the blowing agent in the black liquor, it is more sensible in the absence of crosslinker. In every case, The BET specific surface area remains low indicating that the porosity is only due to macro droplets of about $30-100 \mu \mathrm{m}$.

\section{Conclusion}

In this study, we have established that PMHS, when finely divided as an oil-in-water emulsion, rapidly generate high amount of hydrogen when added to a strongly alkaline solution such as potassium hydroxide without the need of any additional catalyst. This method is very promising as cheap, safe and re-usable on-demand hydrogen generation device using no toxic components and 
simple handlings. Moreover, PMHS is very accessible as waste of the silicon industry and can also be easily regenerated from its polysiloxanes final products. Furthermore, its potential as room temperature blowing agent is promising for the future development of fully bio-based emulsionderived materials.

\section{Conflicts of interest}

There are no conflicts to declare

\section{References}

${ }^{1}$ J. O'N. Bockris, Veziroğlu. Int. J. Hydrogen Energ., 1983, 8, 323.

${ }^{2}$ I. Dincer, C. Zamfirescu, Chapter 1 - Fundamental Aspects. in I. Dincer and C. Zamfirescu. Sustainable Hydrogen Production, I. Dincer and C. Zamfirescu, Editors. 2016, Elsevier. p. 1-63.

${ }^{3}$ Y. Hermans, A. Klein, H. P. Sarker, M. N. Huda, H. Junge, T. Toupance, W. Jaegermann, Adv. Funct. Mater. 2020,1910432.

${ }^{4}$ Md. T. Uddin, O. Babot, L. Thomas, C. Olivier, M. Redaelli, M. D’Arienzo, F. Morazzoni, W. Jaegermann, N. Rockstroh, H. Junge, T. Toupance J. Phys. Chem. C., 2015, 119, 7006.

${ }^{5}$ S. Al Bacha, A.S. Awad, E. El Asmar, T. Tayeh, J.-L. Bobet, M. Nakhl, M. Zakhour Int. J. Hydrogen Energ., 2019, 44, 17515.

${ }^{6}$ J-M. Brunel, Int. J. Hydrogen Energ. 2010, 35, 3401.

${ }^{7}$ J. M. Lavis, R. E. Maleczka, Polymethylhydrosiloxane in Encyclopedia of Reagents for Organic Synthesis (2003), John Wiley \& Sons.

${ }^{8}$ J-M. Brunel, Int. J. Hydrogen Energ., 2017, 42, 23004.

${ }^{9}$ G. A. Smook, Handbook of pulp and paper technologists, Angus Wilde Publications, $3^{\text {rd }}$ ed., Vancouver, 2002.

${ }^{10}$ T. N. Adams, W. J. Frederick, T. M. Grace, M. Hupa, K. Iisa, A. K. Jones, H. Tran, Kraft Recovery Boilers, TAPPI Press, Atlanta, 1997.

${ }^{11}$ M. Cardoso, E. Domingos de Oliveira, M. L. Passos, Fuel, 2009, 88, 756.

${ }^{12}$ M. N. Satheesh, A. K. Mohanty, L. Erickson, M. Misra, J. Biob. Mat. Bioen., 2009, 3, 1.

${ }^{13}$ A-S. Jönsson, A-K. Nordin, O. Walberg, Chem. Eng. Res. Des., 2008, 86, 1271.

${ }^{14}$ A. Foulet, M. Birot, G. Sonnemann, H. Deleuze, Mat. Today Com., 2017, 7, 108.

${ }^{15}$ A. Foulet, M. Birot, G. Sonnemann, H. Deleuze, React. Funct. Polym., 2015, 90, 15.

${ }^{16}$ A. Foulet, M. Birot, G. Sonnemann, H. Deleuze, J. Cleaner Prod., 2015, 91, 181.

${ }^{17}$ C. Forgacz, S. Caubet, Y. Le Guer, B. Grassl, K. El Omari, M. Birot, H. Deleuze J. Polym. Environ., 2013, 21, 683. 
${ }^{18}$ C. Forgacz, M. Birot, H. Deleuze, J. Appl. Polym. Sci., 2013, 129, 2606.

${ }^{19}$ M. Jalalian, A. Bismarck, M. Birot, H. Deleuze, R. Woodward, Q. Jiang, React. Funct. Polym., 2018, 145.

${ }^{20}$ R. L. Heck, W. J. Peascoe, Blowing agents in Encyclopedia of Polymer Science and Technology. (2002) 4th Edition, John Wiley \& Sons.

${ }^{21}$ P. Maansson, Holzforschung, 1983, 37, 143.

${ }^{22}$ S. Al Bacha, I. Aubert, O. Devos, M. Zakhour, M. Nakhl, J. L. Bobet., Int. J. Hydrogen Energ., 2020, 45, 15805. https://doi.org/10.1016/j.ijhydene.2020.04.030

${ }^{23}$ S. Brunauer, P.H. Emmett, E.J. Teller, J. Am. Chem. Soc., 1938, 60, 309.

${ }^{24}$ A. S. Awad, E. El-Asmar, T. Tayeh, F. Mauvy, M. Nakhl, M. Zakhour, J. L. Bobet., Energy, 2016, 95, 175 .

${ }^{25}$ M. Huang, O. Liuzhang, L. Jiangwen, W. Hui, S. Huaiyu, Z. Min Zhu., J. Pow. Sources, 2017, 365, 273.

${ }^{26}$ S-L,Li, J-M, Song, J-Y., Uan., J. Alloys Comp., 2019, 772, 489.

${ }^{27}$ SK. Oh, TH. Cho, MJ. Kim, JH. Lim, KS. Eom, DH. Kim, EA. Cho, HS. Kwon., Int. J. Hydrogen Energ., 2017, 42, 7761.

${ }^{28}$ J. A. Moreno Balderrama, M-A. Dourges, A. Magueresse, L. Maheo, H. Deleuze, P. Glouannec Mat. Today Comm., 2018, 17, 466. 